\title{
The Implementation of Tri Hita Karana Culture-Based Character Education at Pasraman Budi Pekerti, Kemenuh Village, Bali
}

\author{
Ida Bagus Putu Arnyana ${ }^{1, *}$ Ida Ayu Made Istri Utami ${ }^{2}$ \\ ${ }^{1}$ Biology Education Study Program, Universitas Pendidikan Ganesha, Singaraja, Indonesia \\ ${ }^{2}$ English Language Education Study Program, Universitas Pendidikan Ganesha, Singaraja, Indonesia \\ *Corresponding author. Email: putu.arnyana@undiksha.ac.id
}

\begin{abstract}
The aims of this study are to investigate and examine the implementation of character education and the dimensions of characters taught at Pasraman Budi Pekerti in Kemenuh Village. The type of this study is qualitative research. The participants who were targeted to be educated at the Pasraman were teenagers from the village aged between 15 - 15 years. Village leaders from Kemenuh, who were actively involved in the implementation of the Pasraman served as research subjects. Yoga Asanas, ethics based on Hindu teachings, Nyastra, Dharma Gita, Mesatua, male and female skills, Tirtayatra, Ngayah, and community service were among the programs utilized at the Pasraman education. The basic principles of Tri Hita Karana, which include harmony with God, harmony with other people, and harmony with the environment, were the foundational ideals used in character education at the Pasraman. Religion, nationalism, integrity, mutual cooperation, and independence were the qualities of character that were taught. The participants character, according to the teachers, was in the "very good" category.
\end{abstract}

Keywords: Pasraman, Tri Hita Karana, Characters.

\section{INTRODUCTION}

Education is a deliberate and planned effort to create a learning environment and learning process in which students actively develop their potential for religious spiritual strength, self-control, personality, intelligence, noble character, and skills required by themselves, the society, the nation, and the country. The role of education, according to the Law on the National Education System of the Republic of Indonesia Number 20 of 2003, is to develop capacities and form the character and civilization of a dignified country in the framework of the nation's intellectual life. National education strives to help students reach their full potential as human beings who believe in and fear the Almighty God, have noble character, are healthy, knowledgeable, capable, creative, independent, and become democratic and responsible citizens.

In addition to preparing its citizens to comprehend science and technology and to be physically and mentally healthy, the education provided fosters piety toward God Almighty as well as noble characters. As a result, the government has been promoting character education since 2011 [1], which has been bolstered by Presidential Regulation No. 87 of 2017 and Permendikbud No. 20 of 2018 concerning character education. Character education is essential for all people, particularly the younger generation, in order for them to become good citizens. Character education develops people's integrity, honesty, loyalty, openness, not taking advantage of others, caring about other people and the social environment, obeying societal laws and norms, caring for the natural environment, being responsible, disciplined, and always doing things as good as possible [2].

Character education is not only carried out by formal education, but also by non-formal and informal education, according to Presidential Regulation No. 87 of 2017 and the Minister of Education and Culture of the Republic of Indonesia No. 20 of 2018. Character education is carried out at schools and universities through formal education. Character education takes place in kindergartens, courses, training institutions, and community learning activity centers through non-formal education. Character education takes place informally in the home and in the surroundings. Character education 
that is planned, systematic, and measurable has only been implemented through formal education in schools and universities, and it is still being developed to reach maximum outcomes, namely the creation of a pious and noble society.

Making Indonesian people pious, noble in character, and citizens who preserve the values of Indonesian culture is enforced not only via formal education, but also through non-formal education, particularly through community learning centers. Pasraman, a community learning center created by the Bali province government under the auspices of the Traditional Village [3]. The community's education plays a critical part in the advancement of its citizens. Plays an important role in providing education [4]. The higher the level of education given by the community; the higher the community's quality will be. Similarly, the greater the quality and community, the better and higher-quality education it delivers.

There are 1488 traditional villages in Bali, which translates as 1488 Pasraman. Pasraman is a location where youngsters aged 12 to 20 years can get nonformal education as part of their continuous educational process [5]. The word Pasraman is derived from the word "asrama," which refers to the location where the teaching and learning process or education takes place. The formation of character and noble character is emphasized in Pasraman education. The Pasraman 's mission is to give education based on Hinduism and Balinese local wisdom in order to help indigenous villagers improve their identity, moral integrity, and quality of life. This is in accordance with who claims that education based on local knowledge is highly valuable since students may put local wisdom into practice so that they can avoid being excluded from their community's culture [6]. Another proposes that character education based on local wisdom is an excellent way to improve the Indonesian character and culture [7].

Since 2006, the Pasraman in Kemenuh Village has been held. Kemenuh Village's "Pasraman Budi Pekerti" is the name of the ceremony. This Pasraman is based on the Tri Hita Karana (THK), which strives to build mastery of Hindu religious teachings, character, and Balinese culture, as well as produce a physically and mentally healthy generation of young people. Although the Pasraman has been in place in Kemenuh Village for a long time, there is no documented information regarding the boarding school's implementation, and the outcomes are in line with the community's expectations.

The goal of this study is to (1) examine how character education was implemented in the Pasraman in Kemenuh village, and (2) to investigate and examine the competencies that were taught, particularly in terms of developing the character of the Kemenuh Village's young generation.
The following are some of the issues addressed in this study: (1) how was character education implemented at the Pasraman in the Kemenuh Village? (2) how were the dimensions of character taught at the Pasraman in Kemenuh Village? The following are the objectives: (1) to investigate and examine the implementation of character education in the Pasraman of Kemenuh village, and (2) to investigate and examine the dimensions of the character taught at the Pasraman in Kemenuh village.

\section{METHOD}

This study is qualitative research. The reasons for using this research method are, (1) the data were obtained directly from the data source, namely the implementers of the Pasraman education, (2) the data obtained were descriptive data that could not be predicted beforehand, (3) it gave meaning to the information provided by the resource persons, (4) the research instrument developed during data collection, (5) the instrument was the researchers themselves, and (6) the data analysis was carried out simultaneously with data collection.

This study was conducted in Kemenuh Village, which is one of Bali's Indigenous Villages and is located 20 kilometers east of Denpasar. Kemenuh Village was chosen as the research location because it practices Pasraman Budi Pekerti based on THK cultures. Pasraman teachers, who were also traditional leaders in Kemenuh village served as data sources for this study. Ida Bagus Made Oka Suprapta, Ida Bagus Nyoman Rusnadana, and Ida Bagus Made Sudibya were the study's resource persons.

Observation (observing Pasraman activities), interviews with resource persons, documentation (gathering documents relevant to Pasraman), and triangulation (data collection combining observation and interview techniques and other data sources) are all data collection techniques. The Miles and Huberman model method was used to conduct the data analysis, which included data reduction, data presentation, and conclusion drawing/verification. Triangulation was used to test the validity of data, including triangulation of data sources, triangulation of techniques, and triangulation of time [8].

\section{RESULTS AND DISCUSSION}

The study took place in Kemenuh Village. This village is administratively situated in Sukawati District, Gianyar Regency, Bali Province. There were almost 2500 people in the population, with 504 families. Agriculture, tourism, tourist-related industries, traders, and public workers were the people's jobs. Education was extensively established in this traditional village, including elementary, junior high, high school, and 
tertiary institutions (diploma, bachelor, master, and doctorate).

"Pasraman Budi Pekerti Desa Adat Kemenuh" is a Pasraman education program run in the Kemenuh Village. Character education based on the Tri Hita Karana (THK) cultures was practiced at this Pasraman. THK is a philosophy that the Balinese people live by and practice. Tri Hita Karana is derived from the words Tri (three), Hita (pleasure or harmony), and Karana (cause). Therefore, Tri Hita Karana refers to three causes of happiness or harmony, namely, harmony with God Almighty, harmony with other people, and harmony with nature (plants, animals, public buildings, water flow, etc.) [9]. The three components of THK are intertwined and must be performed concurrently and appropriately in order for the Balinese people to accomplish their life goals, namely inner and outer happiness.

Pasraman was carried out in accordance with the Bali Provincial Government's guidelines (2009) [3]. The implementation took place in June, during the official school holiday (held 24 times, each meeting lasting for 4 lesson hours). Aside from being conducted based on the schedule, the time was also added when the village performed a ceremony at the temple, which included at least 10 activities per year, as well as community service activities to clean the temple and the environment, which were held once a month on Sundays with other community members.

The Pasraman's participants ranged in age from 12 to 15 years old (6th grade to 15 th grade) (3rd grade of junior high school). The selection was made in accordance with the provincial government's guidelines. In the end, however, all of the teenagers in the village were educated in Pasraman. The purpose of selecting these teenagers was to improve character education, which included both formal and informal education in the family.

Teenagers are a group of people who are between the ages of children and adults. Despite their growth, they have not been able to master their physical and psychological well-being. According to Fatmawaty Riryn, teenagers have an interim status as a result of the positions given by their parents and partly as a result of their own efforts, which gives them some prestige [10]. This condition is linked to the time of transition that happens following sexual maturation (puberty). The transition phase is necessary for them to learn about the values that exist in society so that they can subsequently carry out their adult responsibilities. Therefore, an emancipatory education will help adolescents to let go of their interim status and become responsible adults.
Education practitioners, such as teachers and former teachers in formal education, former members of the regional people's representative council, village chiefs, and other village leaders, served as teachers or instructors in the Pasraman education. Ida Bagus Made Oka Suprapta, Ida Bagus Made Menuh, Ida Bagus Nyoman Rusnadana, Ida Bagus Made Sudibya, Ida Ayu Ketut Kendran, Ida Bagus Nyoman Minaka, and Ida Bagus Putu Alit were the instructors. These instructors were experts in the subject of education, as well as material in both theory and practice. For the Yoga Asanas instructor, they hired a certified yoga instructor, namely I Made Nastra, who was also the treasurer of the village.

The data from interviews and observations were classified using the THK dimensions, Pasraman programs, and indicators of Indonesian national character, and then discussed with the instructors. The character dimensions included religion, nationalism, integrity, independence, and mutual cooperation, according to the Presidential Regulation of the Republic of Indonesia No. 87/2017 and Permendikbud RI No. 20 of 2018 on improving character education. Religious character values show trust in God Almighty, which is reflected in behaviors such as following religious teachings, being tolerant of other religions' worship, and living in peace with other religions' members.

The values of nationalism character are to think, act, and behave in a way that upholds the Indonesian nationality ideals and prioritize the nation's interests over personal and group interests. Integrity character values are based on attempts to make a person trusted in words, deeds, responsibility, discipline, and dedication. An attitude of not relying on others, toughness, creativity, a strong work ethic, professionalism, and the courage to defend the truth are all values of independent character. The mutual cooperation character values display a spirit of cooperation in which individuals work together to solve issues or work together, build communication and friendship, be open, and aid or offer assistance to those in need.

Based on the results of observations and interviews as well as information classification, the data of this study can be presented in Table 1 . 
Table 1. Data from the Interviews and Observations of the Implementation of Tri Hita Karana Culture-Based Character Education

\begin{tabular}{|c|c|c|c|c|c|}
\hline \multirow{2}{*}{ No } & \multirow{2}{*}{ Program } & \multicolumn{3}{|c|}{ Tri Hita Karana's Taught Dimensions } & \multirow{2}{*}{$\begin{array}{l}\text { Embedded } \\
\text { Character } \\
\text { Indicators } \\
\end{array}$} \\
\hline & & Parahyangan & Pawongan & Palemahan & \\
\hline 1 & Yoga asanas & $\begin{array}{l}\text { - Hindu Theory of } \\
\text { Divinity } \\
\text { - Meditation }\end{array}$ & $\begin{array}{l}\text { Exercises to be } \\
\text { disciplined in the } \\
\text { practice of yoga, } \\
\text { independent in the } \\
\text { practice of doing } \\
\text { yoga asanas }\end{array}$ & - & $\begin{array}{ll}\text { - } & \text { Religiosity } \\
\text { - Integrity } \\
\text { - Independence }\end{array}$ \\
\hline 2 & $\begin{array}{l}\text { Religiosity } \\
\text { theory and } \\
\text { ethics in } \\
\text { accordance with } \\
\text { the ethical } \\
\text { teachings /ethics } \\
\text { of Hinduism }\end{array}$ & $\begin{array}{l}\text { Hindu-based } \\
\text { ethical } \\
\text { teachings } \\
\text { Prayer (Tri } \\
\text { Sandya and } \\
\text { PancaBah) }\end{array}$ & $\begin{array}{l}\text { Togetherness and } \\
\text { discipline in } \\
\text { worship. Ethical } \\
\text { behavior, and } \\
\text { respect for citizens } \\
\text { of other faiths. }\end{array}$ & $\begin{array}{l}\text { Maintaining the } \\
\text { cleanliness of the place } \\
\text { of prayer }\end{array}$ & $\begin{array}{l}\text { - Religiosity } \\
\text { - Integrity } \\
\text { - Mutual } \\
\text { Cooperation } \\
\text { - Nationalism }\end{array}$ \\
\hline 3 & $\begin{array}{l}\text { Nyastra or } \\
\text { writing Balinese } \\
\text { script, drawing } \\
\text { Hindu symbols }\end{array}$ & $\begin{array}{l}\text { Mythology of } \\
\text { the Hindu Gods, } \\
\text { Symbols of } \\
\text { Hinduism }\end{array}$ & $\begin{array}{l}\text { Writing Balinese } \\
\text { script, and drawing } \\
\text { Hindu symbols } \\
\text { independently }\end{array}$ & - & $\begin{array}{l}\text { - Religiosity } \\
\text { - Independence }\end{array}$ \\
\hline 4 & $\begin{array}{l}\text { Dharma Gita } \\
\text { (reciting songs } \\
\text { of worship to } \\
\text { God) }\end{array}$ & $\begin{array}{l}\text { The theory of } \\
\text { divinity } \\
\text { Singing songs } \\
\text { to God }\end{array}$ & $\begin{array}{l}\text { Showing solidarity } \\
\text { in the group in } \\
\text { singing a song of } \\
\text { worship to God so } \\
\text { that it sounds } \\
\text { harmonious }\end{array}$ & - & $\begin{array}{l}\text { - Religiosity } \\
\text { - Mutual } \\
\text { Cooperation }\end{array}$ \\
\hline 5 & $\begin{array}{l}\text { Mesatua (telling } \\
\text { the story of good } \\
\text { and bad deeds, } \\
\text { and the values } \\
\text { of heroism) }\end{array}$ & $\begin{array}{l}\text { Bringing up the } \\
\text { good and bad } \\
\text { things in the story }\end{array}$ & $\begin{array}{l}\text { Showing good } \\
\text { behavior according } \\
\text { to the values taught } \\
\text { in the story }\end{array}$ & - & $\begin{array}{l}\text { - Religiosity } \\
\text { - Integrity }\end{array}$ \\
\hline 6 & $\begin{array}{l}\text { The skills of } \\
\text { males and } \\
\text { females (making } \\
\text { the means of } \\
\text { ceremony) }\end{array}$ & $\begin{array}{l}\text { - Hindu ritual or } \\
\text { ritual theory } \\
\text { - Making } \\
\text { ceremonial } \\
\text { facilities } \\
\end{array}$ & $\begin{array}{l}\text { Cooperating, } \\
\text { completing the task } \\
\text { for making the } \\
\text { assigned } \\
\text { ceremonial facilities }\end{array}$ & $\begin{array}{l}\text { Maintaining the } \\
\text { cleanliness of the } \\
\text { workplace }\end{array}$ & $\begin{array}{l}- \text { Religiosity } \\
\text { - Integrity } \\
\text { - Mutual } \\
\text { Cooperation }\end{array}$ \\
\hline 7 & $\begin{array}{l}\text { Tirtayatra } \\
\text { (performing } \\
\text { worship at a } \\
\text { large temple in } \\
\text { Bali) }\end{array}$ & $\begin{array}{l}\text { Mythology } \\
\text { and history } \\
\text { lessons from the } \\
\text { temples visited. } \\
\quad \text { Showing } \\
\text { solemn behavior } \\
\text { in prayer }\end{array}$ & $\begin{array}{l}\text { Showing an attitude } \\
\text { of togetherness and } \\
\text { responsibility in } \\
\text { activities }\end{array}$ & $\begin{array}{l}\text { Maintaining the } \\
\text { cleanliness of the place } \\
\text { of prayer }\end{array}$ & $\begin{array}{l}\text { - Religiosity } \\
\text { - Integrity } \\
\text { - Mutual } \\
\text { Cooperation }\end{array}$ \\
\hline 8 & $\begin{array}{l}\text { Ngayah } \\
\text { (assisting in the } \\
\text { implementation } \\
\text { of ceremonies in } \\
\text { temples and } \\
\text { indigenous } \\
\text { villages) }\end{array}$ & $\begin{array}{l}\text { Assisting in the } \\
\text { implementation of } \\
\text { ceremonies and } \\
\text { discipline in } \\
\text { worship }\end{array}$ & $\begin{array}{l}\text { Mutual Cooperation } \\
\text { in completing tasks, } \\
\text { and being } \\
\text { responsible in } \\
\text { completing tasks }\end{array}$ & $\begin{array}{l}\text { Maintaining the } \\
\text { cleanliness and beauty } \\
\text { of the temple }\end{array}$ & $\begin{array}{l}\text { - Religiosity } \\
\text { - Integrity } \\
\text { - Mutual } \\
\text { Cooperation }\end{array}$ \\
\hline 9 & $\begin{array}{l}\text { Devotional work } \\
\text { to clean the } \\
\text { temple area and } \\
\text { the customary } \\
\text { village } \\
\text { environment }\end{array}$ & - & $\begin{array}{l}\text { Being disciplined in } \\
\text { work, and } \\
\text { responsible }\end{array}$ & $\begin{array}{l}\text { Theory of } \\
\text { environmental } \\
\text { conservation. Doing } \\
\text { greening in the Dalem } \\
\text { temple environment. } \\
\text { Maintaining cleanliness } \\
\text { and environmental } \\
\text { sustainability of temples } \\
\text { and traditional villages }\end{array}$ & $\begin{array}{l}\text { - Integrity } \\
\text { - Mutual } \\
\text { Cooperation }\end{array}$ \\
\hline
\end{tabular}


Religiosity, nationalism, integrity, mutual cooperation, and independence were the dimensions of character that were taught in Pasraman Budi Pekerti, according to the findings of the study displayed in Table 1 , as well as the results of discussions with the instructors. The mastery of these character dimensions was very good, according to the instructors' views. Participants' conduct during Pasraman activities and in daily life in the village was observed for all dimensions and indications of the characters. Furthermore, in Kemenuh Village, there had never been any issues or delinquency committed by teenagers. As a result, the instructors were quite pleased with the outcomes. Similarly, the members of the village community were pleased that their children were receiving an education at Pasraman Budi Pekerti. A description of all the programs implemented can be given based on the data above.

According to Nurlaili Siti M, the values inherent in Yoga Asanas are: harmonizing the physical, moral, psychological, and spiritual dimensions to build a physically and psychologically healthy human beings [11]. Yoga asanas were followed by meditation, which entailed relaxing and concentrating the mind to achieve a sense of serenity and peace. The mind was focused on drawing closer to God Almighty through meditation. Yoga asanas practiced by elementary school students, according to Astuti, can enhance students' cognitive function and character, particularly in the independent, religious, and integrity aspects [12]. By practicing yoga followed by meditation, human resources who are physically and mentally healthy will be formed and they will have a good work ethic.

The concepts of divinity and ethics or morality were taught in Pasraman education according to Hindu beliefs. In this session, the participants learned about Hindu divinity and how there was only one God, according to Hindu scriptures. Ekam Eva Adityam Brahman was found in the Vedas, which implies that God is the only one and there is no second one. God has been given several titles based on his function in the universe.

Pasraman taught ethics or morality with the goal of learners understanding how to act ethically according to Hindu teachings. In Hinduism, ethics or morality is stated to be a science that examines values, the good and evil of an action, what should be done, and what should be avoided in order to foster a positive human-to-human interaction according to Subawa citing from Lontar Tutur Parakriya [13] and Dirna Putu Prysthia quoting from the Upanishad [14]. It is hoped that good human resources or decent individuals would emerge from this Pasraman.

Participants learned to write Balinese script and draw Hindu symbols during the Nyastra lesson. Participants learned and wrote in Balinese script, which is an important element of Balinese culture. Participants' faith in God Almighty was strengthened by drawing Hindu religious symbols such as Rerajahan (holy symbols of Hindu religious teachings) and depictions of Hindu gods. Participants in this lesson had to be able to write and draw symbols independently in order to develop human resources who understood and could present themselves as Balinese. In this lesson, religious and independent characteristics were emphasized.

The lesson in Dharma Gita was about singing worship hymns to God. The objective of Dharma Gita, according to Sudirga Ida Bagus, is to create a sense of devotion, nurture a sense of sincerity, and quietness in worshiping God Almighty [15]. This skill is important not only for developing a sense of devotion to God, but also for preserving one of the forms of Balinese arts, which is Balinese culture. They were sung together in the Dharma Gita songs to produce a brilliant rhythm. The value of art could not be increased if the sense of togetherness in singing the songs of Dharma Gita was neglected. Religious character and togetherness could be developed through Dharma Gita lessons (mutual cooperation).

Telling stories about good and bad acts, as well as heroic values, was included Mesatua lesson. The objective was to teach truth and virtue that are carried out in accordance with the concept of beauty. Truth and virtue as Hindu skills (competencies) and beauty as Balinese appearances (performances) might be acquired through Mesatua, according to Siryadana I Made. Participants in the Mesatua lesson were taught about positive acts that had to be performed and implemented in daily life in order to develop a character that was appreciated by everybody [16].

Male and female skills lessons were taught to make Hindu religious celebration facilities such as kelatkat, sengkui, katik satay, penjor, kise, klangsah (for males), canang sari, segehan, daksina, lamak, and basic ceremonial facilities (for females). This activity involved learning while joking in order to foster intimacy among the participants. Because the celebration was presented before God Almighty, Siryadana I Made emphasized that building ceremonial facilities must be founded on a clean and pure mind [16]. The significance of the ritual was primarily influenced by the purity of the mind of the person who performed it. The character of togetherness or mutual cooperation, religion, and responsibility to finish the work were all taught in skill classes to the males and females. Furthermore, they were accountable for cleaning up the remnants of the items utilized during work.

Tirtayatra is a Pasraman activity that invited all Pasraman participants to join them on a holy tour to Bali's major temples to worship. The goal of Tirtayatra was to draw closer to God Almighty and learn about the 
history of Bali's major temples. Furthermore, this activity taught self-discipline on holy trips, particularly when worshiping at the targeted temple and being accountable for all the goods brought. In the Tirtayatra journey, purity of heart and preserving togetherness became the foundation. Religious character, honesty, and togetherness, or mutual cooperation, were all taught throughout Tirtayatra activities.

Ngayah is a social obligation in Bali. In traditional communities or sacred places, Ngayah is generally done with mutual assistance (temples). Regardless of educational level, career, or social position, everyone can participate in Ngayah. During the ceremony at the temple in the village, the Pasraman participants participated in Ngayah activities. In the village, there were at least four big temples. Twice a year, each temple celebrated its anniversary (wali). The concept of Ngayah was to assist in the performance of the ritual from the beginning to the end. Because God was served, Ngayah at the temple was founded on a sense of true sincerity and devotional prostration. In addition, Ngayah activities were accountable for the completion of the ceremony's preparation and implementation, as well as the temple's cleanliness. As a result, religion, mutual cooperation, and integrity were taught as character values in Ngayah activities.

Indigenous villagers were responsible for the preservation and cleanliness of holy places and customary village areas. Kemenuh Village organized a community service project once a month that included all traditional village members, including the Pasraman participants. Cleaning temples or holy places was a common responsibility assigned to the Pasraman participants. Cleaning at holy places, like Ngayah activities, required mutual cooperation and responsibility for working until the area was clean. The Pasraman participants enjoyed their work while joking with their friends. The boarding school participants learned to become indigenous people who could do traditional work in mutual cooperation.

Community service and Ngayah activities were activities that prepared people to become village residents who would one day be able to perform adult responsibilities in the villages. The villages trained their young generation to be successors in the preservation of Hinduism and Balinese culture through these events. Bali is prepared to be an island of a thousand temples, with a culture that has been adored by all human beings all over the world. It is of no coincidence that every year, Bali is the most popular tourist destination for visitors from all over the world.

Character education in Kemenuh Village could help the government of the Republic of Indonesia develop citizens who were faithful to the God Almighty, who have noble character, who are physically and mentally healthy, independent, tough, and responsible.
"Developing good people is much more essential than developing smart people, since good people will always be smart, but smart people will not always be good." Good individuals demonstrate this by always behaving well in order to be loved by everyone. Good people would always like to learn to advance their own lives so that good people would definitely be smart

\section{CONCLUSIONS}

The following are the conclusions that may be made from this study. (1) The Pasraman in Kemenuh Village developed a Pasraman Budi Pekerti based on the Tri Hita Karana values. This Pasraman taught character education to its participants in addition to providing skills to help the establishment of Hinduism and Balinese culture. (2) The dimensions of character that were instilled in the participants of Pasraman Budi Pekerti were religion, nationalism, integrity, mutual cooperation, and independence, these dimensions were learned through programs: Yoga Asanas, Hindu religious theory and ethics, Nyastra, Dharma Gita, Mesatua, male and female skills, Tirtayatra, Ngayah, and community service. All of these programs were based on the Tri Hita Karana values.

Suggestions that could be given are: (1) Kemenuh Village continues to organize Pasraman education of higher quality; (2) the villagers are expected to give full support to Pasraman Budi Pekerti because this education can improve the character of the younger generation so that they can be good adults.

\section{REFERENCES}

[1] Fasli Jalal. (2011). Pemerintah Canangkan Pendidikan Karakter. Kompas.com tanggal 13 Juli. Hal https://nasional.kompas.com/read/2011/07/13/0458 0874/

[2] Chrisiana Wanda (2005). Upaya Penerapan Pendidikan Karakter bagi Mahasiswa: Studi Kasus di Jurusan Teknik Industri Uk Petra. Jurnal Teknik Industri VOL. 7, NO. 1, Juni hal 83 - 90

[3] Pemerintah Provinsi Bali. (2009). Materi Panduan Pasraman Remaja untuk Instruktur. Denpasar: Percetakan Buku-buku Penuntun Agama Hindu.

[4] Sada Heru Juabdin. (2017). Peran Masyarakat dalam Pendidikan Perspektif Pendidikan Islam. Jurnal Pendidikan Islam, Volume 8, No I hal 117 125.https://doi.org/10.24042/atjpi.v8i1.2120

[5] Sura, I.G. (2009). Materi Panduan Pasraman Remaja. Debpasar: Penerimtah Provinsi Bali

[6] Fajarin U. (2014). Peranan Kearifan Lokal dalam Pendidikan Karakter. Jurnal Sosio 
[7] Suyitno Imam. (2012). Pengembangan Pendidikan Karakter dan Budaya Bangsa Berwawasan Kearifan Lokal. Jurnal Pendidikan Karakter, Tahun II, Nomor 1, Februari hal.1-13

[8] Sugiyono. (2020). Metode Penelitian Kualitatif. Bandung: Penerbit Alfabeta

[9] Atmaja Bawa Nengah (2020). Wacana Postgenerik Tri Hita Karana pada Masyarakat Bali. Depok: Rajawali Press.

[10] Fatmawaty Riryn (2017) m .Jurnal Reforma Fakultas Keguruan dan Ilmu Pendidikan, UNISLA Vol. VI No. 02,hal 55-65

[11] Nurlaili Siti M (2004). Nilai-nilai Filosofis yeng Terdapat pada Yoga Sutra Patanjali. Jurnal Filsafat. 38(3) hal. 284-290

[12] Astuti, Ni Putu Eni,dan Putu Beny Pradnyana (2020). Praktik Yoga Asanas Dalam Meningkatkan Daya Kognitif Siswa Sebagai Implementasi Pendidikan Karakter. Jurnal Pendidikan Guru Sekolah Dasar Volume 9 Nomor 5 hal. 634-644

[13] Subawa I Made Pasek (2019. Ajaran Tattwa Dan Etika Dalam Lontar Tutur Parakriya. Jurnal Sphatika Volume X No. 1. Hal. 26-36

[14] Dirna Putu Prysthia (2021). Ajaran Etika Dalam Upanisad Bagi Remaja Hindu Di Era Global. JAPAM (Jurnal Pendidikan Agama) Vol. 1, No. 1 hal $77-83$

[15] Sudirga Ida Bagus. (2017). Peranan Dharmagita dalam Meningkatkan Sradha dan Bhakti Siswa Hindu. Vidya Samhita, Jurnal Penelitian Agama, III (1) hal 85-96

[16] Siryadana I Made (2020). Pembentukan Karakter Anak Melalui Kegiatan Pasraman Lascarya Parama Seva di Desa Tianyar Kecamatan Kubu Kabupaten Karangasem. Jurnal Vidya Wertta Volume 3 Nomor 2. Hal 52-70 